\title{
Major genes affecting ovulation rate in sheep
}

\author{
George Henry DAVIS* \\ AgResearch, Invermay Agricultural Centre, Private Bag, Mosgiel, New Zealand
}

(Accepted: 21 May 2004)

\begin{abstract}
Research conducted since 1980 in relation to inheritance patterns and DNA testing of major genes for prolificacy has shown that major genes have the potential to significantly increase the reproductive performance of sheep flocks throughout the world. Mutations that increase ovulation rate have been discovered in the BMPR-1B, BMP15 and GDF9 genes, and others are known to exist from the expressed inheritance patterns although the mutations have not yet been located. In the case of $B M P 15$, four different mutations have been discovered but each produces the same phenotype. The modes of inheritance of the different prolificacy genes include autosomal dominant genes with additive effects on ovulation rate (BMPR-1B; Lacaune), autosomal over-dominant genes with infertility in homozygous females (GDF9), X-linked overdominant genes with infertility in homozygous females (BMP15), and X-linked maternally imprinted genes $(\mathrm{FeCX} 2)$. The size of the effect of one copy of a mutation on ovulation rate ranges from an extra 0.4 ovulations per oestrus for the $F e c X 2$ mutation to an extra 1.5 ovulations per oestrus for the $B M P R-1 B$ mutation. A commercial DNA testing service enables some of these mutations to be used in genetic improvement programmes based on marker assisted selection.
\end{abstract}

major gene / ovulation rate / sheep / reproduction

\section{INTRODUCTION}

In 1980, at a workshop on the Booroola Merino at Armidale, Australia, Piper and Bindon [30] reported on their analysis of litter size records from a small data set of Booroola Merino sheep. They concluded that these "seriously raised the possibility that the exceptional fecundity of the Booroola Merino may in part result from the action of a single major gene (or closely linked group of genes) affecting ovulation rate". This was the first time that the existence of a major gene affecting prolificacy had been suggested and at that time there were many sceptics who strongly doubted that a trait as complex as reproduction could be profoundly influenced by a single gene. Conclusive evidence in support of Piper and Bindon's [30] hypothesis was provided two decades

\footnotetext{
*Corresponding author: george.davis@agresearch.co.nz
} 
later when three groups of researchers almost simultaneously discovered that the inheritance of prolificacy observed in the Booroola Merinos was the result of a mutation in the bone morphogenetic protein 1B receptor (BMPRIB) $[28,34,38]$. Meanwhile the notion of major genes affecting prolificacy in sheep was no longer regarded as genetic heresy. A mutation in the bone morphogenetic protein 15 gene (BMP15, also known as GDF9B) responsible for high prolificacy in Inverdale sheep had been discovered by Galloway et al. [16] and evidence of segregating major genes was being reported from flocks around the world. A large or major gene is typically one where the difference between the homozygotes is at least 0.5 standard deviations, which for the ovulation rate includes genes where a single copy increases ovulation rate by more than about 0.2 . This paper reviews the major genes and putative major genes affecting prolificacy in sheep (Tab. I) that have been described since Piper and Bindon's [30] initial observation.

\section{BOOROOLA GENE}

In the early 1980's, records of litter size [30] and ovulation rate [6] from Booroola Merinos and their crosses showed evidence of a segregating autosomal major gene $(\mathrm{FecB})$ with an additive effect on ovulation rate and a partially dominant effect on litter size. Ewes inheriting one copy of the Booroola gene from either parent produced about 1.5 extra eggs and gave birth to about 1.0 extra lamb per ewe lambing. Homozygous carriers produced about 3.0 extra eggs resulting in about 1.5 extra lambs per ewe lambing. The Booroola Sheep Society of NZ established the first sheep registry for a major gene in the early 1980's. A certification procedure was incorporated whereby rams were assigned single copy or double copy status on the basis of information on the ovulation rate or litter size of daughters provided by the breeder.

In 1993, the first DNA marker test for the Booroola gene, located on chromosome 6, was developed [27]. This test was about 90\% accurate and relied on three marker genes located near the Booroola gene. The Booroola status of the animal's parents was required to determine the phase of each marker. The marker test was accepted by the Booroola Sheep Society of NZ as an alternative to progeny testing for the purpose of certifying rams as carriers. The big breakthrough came in 2001 when groups at AgResearch in New Zealand, INRA in France, and the University of Edinburgh in Scotland discovered that sheep carrying the Booroola gene have a mutation in a receptor $(B M P R-1 B)$ expressed in the ovary $[28,34,38]$. The discovery of the actual gene enabled a commercial DNA test to be developed that is $100 \%$ accurate and requires no 
Table I. Known and putative major genes for prolificacy in sheep.

\begin{tabular}{|c|c|c|c|c|c|}
\hline Gene & Name & $\begin{array}{l}\text { Allele } \\
\text { symbol }\end{array}$ & Chr & $\begin{array}{c}\text { Effect on ovulation rate (OR) } \\
\text { and litter size (LS) }\end{array}$ & $\begin{array}{c}\text { Founder } \\
\text { breed }\end{array}$ \\
\hline$B M P R-1 B$ & Booroola & $\mathrm{FecB}^{B}$ & 6 & $\begin{array}{l}B+: \text { OR +1.5; LS +1.0 } \\
B B: \text { OR +3.0; LS +1.5 }\end{array}$ & $\begin{array}{l}\text { Merino, } \\
\text { Garole and } \\
\text { Javanese }\end{array}$ \\
\hline BMP15 & Inverdale & $\mathrm{Fec} X^{I}$ & $X$ & $\begin{array}{l}I+: \text { OR }+1.0 ; \text { LS }+0.6 \\
I I: \text { Infertile (streak ovaries) }\end{array}$ & Romney \\
\hline BMP15 & Hanna & $F e c X^{H}$ & $\mathrm{X}$ & $\begin{array}{l}H+: \text { OR }+1.0 ; \text { LS }+0.6 \\
H H: \text { Infertile (streak ovaries) }\end{array}$ & Romney \\
\hline BMP15 & Belclare & $\mathrm{Fec} X^{B}$ & $\mathrm{X}$ & $\begin{array}{l}B+: \text { OR }+1.0 \\
B B: \text { Infertile (streak ovaries) }\end{array}$ & Belclare \\
\hline BMP15 & Galway & $\mathrm{Fec} X^{G}$ & $\mathrm{X}$ & $\begin{array}{l}G+: \text { OR }+0.7 \\
G G: \text { Infertile (streak ovaries) }\end{array}$ & $\begin{array}{c}\text { Belclare } \\
\text { and } \\
\text { Cambridge }\end{array}$ \\
\hline BMP15 & - & - & $\mathrm{X}$ & Undetermined phenotype & Lacaune \\
\hline GDF9 & $\begin{array}{l}\text { High } \\
\text { Fertility }\end{array}$ & $\mathrm{Fec}^{H}$ & 5 & $\begin{array}{l}H+: \text { OR }+1.4 \\
H H: \text { Infertile (streak ovaries) }\end{array}$ & $\begin{array}{l}\text { Belclare } \\
\text { and } \\
\text { Cambridge }\end{array}$ \\
\hline- & Woodlands & $\mathrm{FecX} 2^{W}$ & $\mathrm{X}$ & $\begin{array}{l}W+: \text { OR }+0.4 ; \mathrm{LS}+0.25 \\
W W: \text { OR \& LS } \geq \mathrm{W}+\end{array}$ & Coopworth \\
\hline- & Lacaune & Fec $L^{L}$ & 11 & $\begin{array}{l}L+: \mathrm{OR}+1.0 \\
L L: \mathrm{OR}+2.0\end{array}$ & Lacaune \\
\hline- & Thoka & $\mathrm{FecI}^{I}$ & - & $\begin{array}{l}I+: \mathrm{OR}+1.2 ; \mathrm{LS}+0.7 \\
I I: \text { some evidence of } \\
\text { infertility }\end{array}$ & Icelandic \\
\hline- & - & - & - & $\begin{array}{l}\text { Putative heterozygotes: OR } \\
+1.0 ; \mathrm{LS}+0.6\end{array}$ & Olkuska \\
\hline- & - & - & - & $\begin{array}{l}\text { High variation in OR (1-8) } \\
\text { and LS (1-7), and high } \\
\text { repeatability of OR }(0.8)\end{array}$ & Belle-Ile \\
\hline
\end{tabular}

parental information. This test is operated by the Genomnz laboratory at the AgResearch Invermay Agricultural Centre.

The availability of the new accurate test without the need for parentage information has provided new insights into the possible origin of the Booroola Merino. A recent study investigating the gene's origin led to its discovery in dwarf Garole sheep in northeast India [13]. The Garole (also known as Bengal) were introduced into Australia in 1792, and it is highly likely that the Booroola Merino is a direct descendant of these sheep [36]. The prolific Javanese sheep of Indonesia, previously known as $\mathrm{FecJ}$ [5], also carry the Booroola gene [13].

Uptake of the Booroola gene has been limited due to past difficulties in identifying carrier sheep and the extra management required to profitably 
benefit from the very large increase in litter size. However, sheep carrying the Booroola gene derived from the Australian Booroola Merino are farmed in at least 13 countries [35], in addition to native breeds carrying the $B M P R-1 B$ mutation in India and Indonesia [13].

\section{INVERDALE GENE}

The inheritance pattern of the Inverdale gene (FecX) was discovered in 1990 in a screened prolific flock among descendants of a Romney ewe that had produced 33 lambs in 11 lambings in a Banks Peninsula flock [8]. In the mid 1990's in the Romney flock of Mac Hanna in Waikato, a gene showing the same inheritance pattern and phenotype as the Inverdale was found [10]. The observation that in both Inverdale and Hanna sheep a carrier ram passed the gene to all daughters but to none of his sons was the first indication that in both flocks a prolificacy gene was inherited on the X-chromosome. In contrast, carrier ewes passed the gene to half their progeny of each sex.

One copy of the Inverdale $\left(F e c X^{I}\right)$ allele or Hanna $\left(F e c X^{H}\right)$ allele increase litter size by about 0.6 lambs per ewe lambing. However, homozygous ewes inheriting alleles from both parents have small undeveloped ovaries and are infertile. In the late 1990's, a DNA marker test for the Inverdale gene was developed and had a similar accuracy to the early Booroola marker test [15]. The test also relied on three DNA markers and needed information on the Inverdale status of parents of the sheep under test. In 2000, research at the AgResearch Molecular Biology Unit in collaboration with researchers at Wallaceville and in Finland, showed that Inverdale sheep have a mutation in an ovary-derived growth factor gene (BMP15) [16]. Interestingly, this showed that both Inverdale and Hanna sheep have mutations of BMP15 but the Hanna allele $\left(F e c X^{H}\right)$ has a different mutation than the Inverdale allele $\left(F e c X^{I}\right) . F e c X^{I}$ individuals have a single nucleotide substitution of the mature coding sequence whereas $F e c X^{H}$ individuals have a single nucleotide substitution resulting in a premature stop codon. The discovery of the actual mutation has enabled a new DNA test to be developed which, like the new Booroola test, is $100 \%$ accurate and requires no parental information. The DNA test for the Inverdale gene is also available at the Genomnz Laboratory at the AgResearch Invermay Agricultural Centre. A recently developed simplified blood sampling procedure, involving a few drops of blood on a special absorbent paper, has greatly reduced the cost of sampling sheep for DNA testing and provides for easier handling and storage of the samples. 
With the use of a simplified sampling procedure and the availability of a $100 \%$ accurate test, the use of the Inverdale gene in the NZ sheep industry has recently increased, mainly through Romney and Texel rams carrying the gene. Ewes inheriting the gene from both parents are infertile, and therefore commercial use of the gene involves retaining the prolific daughters of a carrier ram crossed with non-Inverdale ewes. These daughters are identified and managed as high producing ewes that are mated to terminal sires. In one leading commercial flock in New Zealand, Inverdale ewes averaged an extra 35 lambs weaned per 100 ewes joined per year, over a four-year period. A cost benefit analysis published in 1998 showed that the economic value under typical NZ farming conditions of an Inverdale ram compared with a non-Inverdale ram was \$NZ3350 [1].

\section{WOODLANDS GENE}

In 1999, the inheritance pattern of the Woodlands prolificacy gene $\left(\mathrm{FecX} 2^{W}\right)$ was discovered in Coopworth sheep in a screened prolific flock [11]. This flock has been traced back to the early establishment of the breed by interbreeding Border Leicesters with Romneys at Lincoln College in the 1960's. One copy of the Woodlands gene increases litter size by about 0.25 extra lambs per ewe lambing. This gene, like Inverdale and Hanna, is on the X-chromosome, which means that rams can only inherit it from their dam whereas ewes can inherit it from either carrier parent. However, unlike Inverdale and Hanna, the Woodlands gene is maternally imprinted. When ewes inherit the gene from their sire (paternal inheritance) the gene is expressed as an increased litter size, but when ewes inherit the gene from their dam (maternal inheritance) the effect of the gene is silenced and there is no increase in litter size. Furthermore, rams inheriting the gene from dams that express the gene have daughters in which the gene is silenced. On the contrary, rams inheriting the gene from dams where the gene is silent have daughters in which the gene is expressed.

The effect of two copies of the gene on litter size has not been determined and a progeny test is presently being carried out to measure the effect in homozygous carriers. However, it is known that two copies of the Woodlands gene do not cause infertility as occurs in ewes with two copies of the Inverdale and Hanna genes. Another family line of Coopworth sheep descending from a prolific ewe in a South Otago flock shows the same unusual inheritance pattern [12] and research is continuing to determine whether this Metherell allele is the same as the Woodlands. There is strong evidence that the Woodlands or Metherell gene is already present in a number of leading stud Coopworth 
flocks where it manifests itself by the apparent spontaneous appearance of a ram that produces prolific daughters. The undetected presence of the gene in a flock will result in misleading breeding values for the number of lambs born because these are calculated on the basis of multigenic inheritance and are not designed to account for major genes. The complicated inheritance pattern of this gene dictates that its future impact on sheep production will be dependent upon the development of a genetic marker test to identify carrier sheep. This research is in progress with a progeny test involving 30 rams but it could take a number of years before a DNA test is available.

\section{CAMBRIDGE}

The Cambridge breed was established from a population of prolific ewes screened from the UK national sheep flock. High phenotypic variance and high repeatability for ovulation rate in Cambridge sheep led Hanrahan and Owen [20] to suggest that a major gene is segregating in this population and the effect of one copy is to increase ovulation rate by about 0.7 . In addition to the high ovulation rate in Cambridge sheep, Hanrahan [18] noted a very high incidence of abnormalities of the reproductive tract (14\%), specifically inactive or hypoplastic ovaries. One of the propositions of Owen [29] is that this condition could represent the homozygous condition of an X-linked locus as reported for the Inverdale gene. In 1998, laparoscopic observation of the ovaries in barren Cambridge ewes confirmed that the appearance of their ovaries was identical to that seen in homozygous Inverdale sheep (Davis, unpublished observations) and it has recently been discovered that a mutation of the BMP15 gene is present in the Cambridge flock [21]. This mutation, designated $\mathrm{Fec} \mathrm{X}^{G}$, is different to either the Inverdale $\left(\mathrm{Fec} \mathrm{X}^{I}\right)$ or Hanna $\left(\mathrm{Fec} \mathrm{X}^{H}\right)$ mutations but the heterozygous phenotype (increased ovulation rate) and homozygous phenotype (infertile with streak ovaries) are identical to Inverdale and Hanna alleles. Furthermore, the flock also has a mutation in the autosomal GDF9 gene $\left(\mathrm{FecG} \mathrm{G}^{\mathrm{H}}\right)$ on chromosome 5 that likewise causes increased ovulation rates in heterozygous ewes and infertility in homozygous carriers [21]. One copy of $\mathrm{FecG}^{H}$ is estimated to increase the ovulation rate by 1.4.

\section{BELCLARE}

Hanrahan [18] described a family line within the screened prolific Belclare breed in Ireland that shows very high ovulation rates. High ovulation rates and 
a high repeatability suggested a possible major gene effect. However, Hanrahan [18] noted some inconsistencies in the inheritance pattern and concluded that a one locus model may be too simple a hypothesis. He also noted that following the interbreeding of Belclare ewes there was a high incidence of sterility among female progeny [19]. Three segregating major genes have since been found in this Belclare line [21]. There were two mutations of BMP15, one of which is the same as the BMP15 mutation in the Cambridge sheep $\left(\mathrm{FecX}{ }^{G}\right)$, and the other $\left(F e c X^{B}\right)$ which was not previously discovered. The same GDF9 mutation found in the Cambridge $\left(F e c G^{H}\right)$ is also present in the Belclare. Ewes with two copies of any of these three mutations or one copy of $F e c X^{G}$ together with one copy of $\mathrm{FecX}^{B}$ are sterile. Heterozygous carriers of $\mathrm{FecX} \mathrm{X}^{G}$ or $\mathrm{FecX} \mathrm{X}^{B}$ show similar increases in ovulation rate to sheep heterozygous for $F e c X^{I}$ or $\mathrm{FecX} \mathrm{X}^{H}$, and the effect of one copy of $\mathrm{Fec} \mathrm{G}^{H}$ was the same in the Belclare as in the Cambridge breed.

\section{LACAUNE}

In 1998, records from an industry-based selection programme in the French Lacaune meat sheep revealed a high heritability of litter size $\left(\mathrm{h}^{2}=0.4\right)$ and individuals with litter records $\geq 4$, suggesting the presence of a segregating major gene for prolificacy in this breed [3]. A subset of these Lacaune sheep screened on the basis of their high prolificacy had a mean ovulation rate of 5.8 with individual records ranging from 3 to 14, and a very high repeatability of ovulation rate (0.87) [2]. Progeny testing and a subsequent segregation analysis supported the earlier data and indicated the presence of an autosomal gene with one copy increasing the ovulation rate by 1.03 [24]. Further analysis of records from the subset of ewes and progeny test data from three rams and 12 of their sons in a backcross experiment enabled putative heterozygous and homozygous ewes to be compared and this indicated that the effect of the gene is additive for ovulation rate in a manner similar to that of the Booroola gene [4]. A genome scan localised the Lacaune gene to chromosome 11 and identified 10 markers around the Lacaune locus [24].

The presence of some ewes with extremely high ovulation rates led Bodin et al. [4] to speculate that several alleles may be present or possibly other major genes within the screened group of ewes. Recently a mutation of BMP15, different from $\mathrm{FecX} \mathrm{X}^{I}, \mathrm{FecX} \mathrm{X}^{H}, \mathrm{FecX} \mathrm{X}^{G}$ and $\mathrm{FecX} \mathrm{X}^{B}$, has been discovered in the Lacaune breed and work is in progress to determine the phenotype of ewes carrying this mutation (Bodin, personal communication). 


\section{THOKA GENE}

The discovery of a segregating major gene in Booroola sheep prompted Jonmundsson and Adalsteinsson [23] to search the records of a prolific line of Icelandic sheep. They discovered that almost all Icelandic ewes with multiple births descend from a ewe named Thoka that had at least two records of triplets at a time when even twins were quite rare, and suggested that the effect was due to a major gene $(F e c I)$. The litter size of putative heterozygous ewes, assigned their genotype on the basis of at least one record of a triplet litter, was 0.64 higher than putative non-carriers. Infertility was also recorded in 7 out of 46 daughters $(15.2 \%)$ where a putative heterozygous ram was mated to putative heterozygous ewes [23]. Recently, a segregation analysis on 14 years' litter size data was carried out on a Thoka flock in the UK [37] which had been established in 1985 by crossbreeding Icelandic Thoka sheep with Cheviots [32]. The results showed strong evidence for an additive autosomal major gene that increases litter size by 0.70 lambs per ewe lambing, which is similar to the previous estimates reported by Jonmundsson and Adalsteinsson [23] and Rhind et al. [31]. The chromosomal location of the gene is unknown and DNA tests from a sample of putative heterozygous ewes showed that neither the autosomal Booroola nor X-linked Inverdale mutation are present [13].

\section{OLKUSKA}

Martyniuk and Radomska [26] proposed that a possible major gene for prolificacy, similar to the Booroola gene, is segregating in the Polish Olkuska breed. They assigned ewes a genotype on the basis of ovulation rate records (heterozygous ewes had at least one record of ovulation rate $\geq 3$, and homozygous carrier ewes had at least one record of ovulation rate $\geq 5$ ) and estimated that the effect of one copy of the putative gene was about one extra egg per ovulating ewe. Kaczor et al. [22] were unable to show any significant relationships between blood protein polymorphisms and the putative Olkuska genotype. Recently, DNA tests from a sample of highly prolific Olkuska ewes showed that neither the Booroola nor Inverdale mutation is present [13]. The Olkuska is an endangered prolific breed which in 2000 comprised only 58 registered ewes in five flocks and its endangered status is listed as "critical-maintained" [33]. Progress in elucidating the inheritance of prolificacy in Olkuska sheep has been slow due to the small population and small flock sizes. 


\section{BELLE-ILE}

High ovulation rates (2.54) and high litter size (2.23) have been recorded in Belle-Ile sheep in France [25]. The high variation in ovulation rate (range 1-8) and litter size (range 1-7) combined with high repeatabilities are characteristic of flocks where a major gene is segregating. The repeatability of ovulation rate was 0.8 which is similar to that recorded in Javanese $(0.6,[5])$, Booroola (0.6-0.7, [7]), Cambridge (0.7, [17]), and Icelandic (0.6-0.8, [14]) sheep, which are all breeds with segregating major genes for prolificacy. These observations together with evidence of Mendelian inheritance of prolificacy in progeny, led Malher and Le Chere [25] to hypothesise that an autosomal major gene for prolificacy is segregating in this breed. Like the Olkuska, the Belle-Ile is classified as an endangered breed and it is maintained in small flocks. For this reason it has not been possible to quantify the size of the effect on ovulation rate and there is currently no further research into the mode of inheritance of this gene.

\section{INTERACTIONS BETWEEN MUTATIONS}

The infertile streak ovary condition observed in ewes that are homozygous for the four BMP15 mutations $\left(F e c X^{I}, F e c X^{H}, F e c X^{G}\right.$ and $\left.F e c^{B}\right)$ has also been observed where ewes carry one copy of each of two alleles. Ewes with a copy of Fec $X^{I}$ and a copy of $F e c X^{H}$ are infertile [10], as are those with one copy of $F e c X^{G}$ and $F e c X^{B}[21]$.

Crossbreeding of sheep carrying a BMP15 mutation with those carrying the $B M P R-1 B$ mutation showed that all daughters have fully functional ovaries and high ovulation rates, averaging 4.36 [9]. One copy of BMP15 and one copy of $B M P R-1 B$ has a multiplicative effect on ovulation rate. The effect of $B M P 15$ is to increase ovulation rate by $44 \%$ and the effect of $B M P R-1 B$ is to increase ovulation rate by $90 \%$. On a proportional basis, the effect of one gene is unaffected by the presence or absence of the other.

Evidence on the effect of one copy of a BMP15 mutation together with one copy of the GDF9 mutation is equivocal. Most of the evidence suggests that the effect of the two genes on ovulation rate is additive, but some progeny test data suggest a smaller response to a copy of GDF9 when a BMP15 mutation is also present [21]. In all instances the individuals with mutations in GDF9 and $B M P 15$ had higher ovulation rates than those with either mutation separately.

A ewe carrying one copy of each of three mutations (BMP15, BMPR-1B and Woodlands) was bred by crossing a progeny tested Woodlands carrier sire 
$\left(\mathrm{FecX} 2^{W / Y}\right.$ ) with a dam that carried copies of $\mathrm{Fec} \mathrm{X}^{I}$ and $\mathrm{FecB} B^{B}$ (Davis, unpublished data). The daughter carrying the three mutations had fully functional ovaries and had ovulation rates of 5 and 8 at 1.5 years of age, and an ovulation rate of 12 at 2.5 years of age.

\section{CONCLUSION}

The establishment of selected prolific flocks by screening prolific ewes from national flocks has proven to be an effective way to detect major genes. These screened flocks in New Zealand, Ireland and the UK have been the basis of the discovery of the $\mathrm{FecX} X^{I}, \mathrm{FeCX} 2^{W}, \mathrm{FecX} X^{B}, \mathrm{FecX} X^{G}$ and $\mathrm{Fec} G^{H}$ mutations. Major genes for prolificacy with differing sizes of effect on ovulation rate and litter size have become a new option for sheep farmers aiming to significantly increase lambing percentages. The incorporation of a major gene for prolificacy into a flock using marker assisted selection allows increased selection pressure on other traits leading to increased genetic gain. A major gene has the advantage that it can be introduced into any new breed while retaining the new breed's characteristics. This is well illustrated in the passage of the Booroola gene from the dwarf Garole breed in India to the fine-wool Merino in Australia, and subsequently to the long-wool Romney in New Zealand. There have been several recent research findings in relation to inheritance patterns and DNA testing of major genes for prolificacy that have the potential to significantly increase the reproductive performance of sheep flocks throughout the world, as well as enhancing knowledge of the control of reproduction across other species, including humans.

\section{REFERENCES}

[1] Amer P.R., McEwan J.C., Dodds K.G., Davis G.H., Cost benefit analysis of commercial use of the Inverdale prolificacy gene, Proc. NZ Soc. Anim. Prod. 58 (1998) 157-160.

[2] Bodin L., Bocquier F., Eychenne F., Effect of reducing feeding supply on ovulation rate in hyper-prolific meat Lacaune breed, Proc. Europe. Assoc. Anim. Prod. 49 (1998) paper SA1.6: p. 208.

[3] Bodin L., Elsen J.M., Poivey J.P., SanCristobal-Gaudy M., Belloc J.P., Eychenne F., Hyper-prolificacy in the French Lacaune sheep breed; a possible major gene, in: Proc. 6th World Cong. Genet. Appl. Livest. Prod., Armidale, 11-16 January 1998, University of New England, Vol. 27, pp. 11-14.

[4] Bodin L., SanCristobal M., Lecerf F., Mulsant P., Bibé B., Lajous D., Belloc J.P., Eychenne F., Amigues Y., Elsen J.M., Segregation of a major 
gene influencing ovulation in progeny of Lacaune meat sheep, Genet. Sel. Evol. 34 (2002) 447-464.

[5] Bradford G.E., Inounu I., Iniguez L.C., Tiesnamurti B., Thomas D.L., The prolificacy gene of Javanese sheep, in: Elsen J.M., Bodin L., Thimonier J. (Eds.), Major Genes for Reproduction in Sheep, Inra, Paris, France, 1991, pp. 67-73.

[6] Davis G.H., Montgomery G.W., Allison A.J., Kelly R.W., Bray A.R., Segregation of a major gene influencing fecundity in progeny of Booroola sheep, N.Z. J. Agric. Res. 25 (1982) 525-529.

[7] Davis G.H., Montgomery G.W., Kelly R.W., Estimates of the repeatability of ovulation rate in Booroola cross ewes, in: Proc. 2nd World Cong. Genet. Appl. Livest. Prod., Madrid, 7-11 October 1982, Vol. 8, pp. 674-679.

[8] Davis G.H., McEwan J.C., Fennessy P.F., Dodds K.G., Farquhar P.A., Evidence for the presence of a major gene influencing ovulation rate on the $\mathrm{X}$-chromosome of sheep, Biol. Reprod. 44 (1991) 620-624.

[9] Davis G.H., Dodds K.G., Bruce G.D., Combined effect of the Inverdale and Booroola prolificacy genes on ovulation rate in sheep, Proc. Assoc. Adv. Anim. Breed. Genet. 13 (1999) 74-77.

[10] Davis G.H., Bruce G.D., Dodds K.G., Ovulation rate and litter size of prolific Inverdale $\left(\mathrm{FecX} \mathrm{X}^{I}\right)$ and Hanna $\left(\mathrm{FecX}{ }^{H}\right)$ sheep, Proc. Assoc. Adv. Anim. Breed. Genet. 14 (2001) 175-178.

[11] Davis G.H., Dodds K.G., Wheeler R., Jay N.P., Evidence that an imprinted gene on the $\mathrm{X}$ chromosome increases ovulation rate in sheep, Biol. Reprod. 64 (2001) 216-221.

[12] Davis G.H., Dodds K.G., Wheeler R., Bruce G.D., Further evidence of nonMendelian inheritance at the FecX2 locus in a prolific sheep flock, in: Proc. 7th World Cong. Genet. Appl. Livest. Prod., Montpellier, 19-23 August 2002, Inra, Castanet-Tolosan, France, Vol. 30, pp. 641-644.

[13] Davis G.H., Galloway S.M., Ross I.K., Gregan S.M., Ward J., Nimbkar B.V., Ghalsasi P.M., Nimbkar C., Gray G.D., Subandriyo, Inounu I., Tiesnamurti B., Martyniuk E., Eythorsdottir E., Mulsant P., Lecerf F., Hanrahan J.P., Bradford G.E., Wilson T., DNA tests in prolific sheep from eight countries provide new evidence on origin of the Booroola (FecB) mutation, Biol. Reprod. 66 (2002) 1869-1874.

[14] Eythorsdottir E., Adalsteinsson S., Jonmundsson J.V., Hanrahan J.P., Research work on the Icelandic Thoka gene, in: Elsen J.M., Bodin L., Thimonier J. (Eds.), Major Genes for Reproduction in Sheep, Inra, Paris, France, 1991, pp. 75-84.

[15] Galloway S.M., Cambridge L.M., Henry H.M., van Stijn T.C., Davis G.H., A genetic test to identify carriers of the ovine Inverdale prolificacy gene $\left(\mathrm{FecX}^{I}\right)$, Proc. NZ Soc. Anim. Prod. 59 (1999) 114-116.

[16] Galloway S.M., McNatty K.P., Cambridge L.M., Laitinen M.P.E., Juengel J.L., Jokiranta T.S., McLaren R.J., Luiro K., Dodds K.G., Montgomery G.W., Beattie A.E., Davis G.H., Ritvos O., Mutations in an oocyte-derived growth factor gene (BMP15) cause increased ovulation rate and infertility in a dosage-sensitive manner, Nat. Genet. 25 (2000) 279-283.

[17] Hanrahan J.P., Phenotypic and genetic variation for ovulation rate in Cambridge sheep, Proc. Brit. Soc. Anim. Prod. Winter Meeting (1989) paper 19. 
[18] Hanrahan J.P., Evidence for single gene effects on ovulation rate in the Cambridge and Belclare breeds, in: Elsen J.M., Bodin L., Thimonier J. (Eds.), Major Genes for Reproduction in Sheep, Inra, Paris, France, 1991, pp. 93-102.

[19] Hanrahan J.P., Major gene effects on reproduction in sheep, Irish J. Ag. Food Res. 35 (1996) 87-88.

[20] Hanrahan J.P., Owen J.B., Variation and repeatability of ovulation rate in Cambridge ewes, Proc. Brit. Soc. Anim. Prod. Winter meeting (1985) paper 37.

[21] Hanrahan J.P., Gregan S.M., Mulsant P., Mullen M., Davis G.H., Powell R., Galloway S., Mutations in the genes for oocyte derived growth factors GDF9 and BMP15 are associated with both increased ovulation rate and sterility in Cambridge and Belclare sheep (Ovis aries), Biol. Reprod. 70 (2004) 900-909.

[22] Kaczor U., Klewiec J., Martyniuk E., Murawski M., Rychlik T., Wierzchos E., Analysis of relationship between blood protein polymorphism and hypothetical genotype in Olkuska fecundity gene carriers, Proc. Europe. Assoc. Anim. Prod. 49 (1998) paper SA1.7: p. 209.

[23] Jonmundsson J.V., Adalsteinsson S., Single genes for fecundity in Icelandic sheep, in: Land R.B., Robinson D.W. (Eds.), Genetics of Reproduction in Sheep, Butterworths, London, UK, 1985, pp. 159-168.

[24] Lecerf F., Mulsant P., Elsen J.M., Bodin L., Localisation and mapping of a major gene controlling ovulation rate in Lacaune sheep, in: Proc. 7th World Cong. Genet. Appl. Livest. Prod., Montpellier, 19-23 August 2002, Inra, CastanetTolosan, France, Vol. 30, pp. 753-756.

[25] Malher X., Le Chere A.K., High prolificacy in Belle-Ile sheep (Brittany, France): major effects of a putative single gene and the $\mathrm{A}^{\text {wh }}$ colour gene on ovulation rate and litter size, Reprod. Nut. Dev. 38 (1998) 473-484.

[26] Martyniuk E., Radomsa M.J., A single gene for prolificacy in Olkuska sheep, in: Elsen J.M., Bodin L., Thimonier J. (Eds.), Major Genes for Reproduction in Sheep, Inra, Paris, France, 1991, pp. 85-92.

[27] Montgomery G.W., Crawford A.M., Penty J.M., Dodds K.G., Ede A.J., Henry H.M., Pierson C.A., Lord E.A., Galloway S.M., Schmack A.E., Sise J.A., Swarbrick P.A., Hanrahan V., Buchanan F.C., Hill D.F., The ovine Booroola fecundity gene $(\mathrm{FecB})$ is linked to markers from a region of human chromosome 4q, Nat. Genet. 4 (1993) 410-414.

[28] Mulsant P., Lecerf F., Fabre S., Schibler L., Monget P., Lanneluc I., Pisselet C., Riquet J., Monniaux D., Callebaut I., Cribiu E., Thimonier J., Teyssier J., Bodin L., Cognie Y., Elsen J.M., Mutation in bone morphogenetic protein receptor-1B is associated with increased ovulation rate in Booroola Merino ewes, Proc. Natl. Acad. Sci. USA 98 (2001) 5104-5109.

[29] Owen J.B., The Cambridge breed, in: Fahmy M.H. (Ed.), Prolific Sheep, CAB International, Wallingford, UK, 1996, pp. 161-173.

[30] Piper L.R., Bindon B.M., The Booroola Merino and the performance of medium non-peppin crosses at Armidale, in: Piper L.R., Bindon B.M., Nethery R.D. (Eds.), The Booroola Merino, Proceedings of a Workshop, Armidale, 24-25 August 1980, CSIRO, 1982, pp. 9-19.

[31] Rhind S.M., Gittus G., Potts J.M., Bishop S.C., Reproductive performance of the Thoka Cheviot sheep, Proc. Brit. Soc. Anim. Sci. (2000) p. 44. 
[32] Russel A.J.F., Alexieva S.A., Elston D.A., The effect of the introduction of the Thoka gene for fecundity on lamb production from Cheviot ewes, Anim. Sci. 64 (1997) 503-508.

[33] Scherf B.D., World Watch List for Domestic Animal Diversity, 3rd edn., FAO, Rome, 2000.

[34] Souza C.J., MacDougall C., Campbell B.K., McNeilly A.S., Baird D.T., The Booroola $(\mathrm{FecB})$ phenotype is associated with a mutation in the bone morphogenetic receptor type 1 B (BMPR1B) gene, J. Endocrinol. 169 (2001) R1-6.

[35] Thimonier J., Davis G.H., Fahmy M.H., Castonguay F., Fernandez-Abella D., Greef J.C., Hofmeyr J.H., Gootwine E., Bor A., Braw-Tal R., Haley C.S., Klewiec J., Gabryszuka M., Slowak M., Piper L.R., Bindon B.M., Veress L., Lengyel A., Paszthy G., Horn P., Visscher A.H., Wassmuth R., Young L.D., The F gene in the world: Use and research objectives, in: Elsen J.M., Bodin L., Thimonier J. (Eds.), Major Genes for Reproduction in Sheep, Inra, Paris, France, 1991, pp. 3-13.

[36] Turner H.N., Origins of the CSIRO Booroola, in: Piper L.R., Bindon B.M., Nethery R.D. (Eds.), The Booroola Merino, Proceeding of a Workshop, Armidale, 24-25 August 1980, CSIRO, 1982, pp. 1-7.

[37] Walling G.A., Bishop S.C., Pong-Wong R., Gittus G., Russel A.J.F., Rhind S.M., Detection of a major gene for litter size in Thoka Cheviot sheep using Bayesian segregation analyses, Anim. Sci. 75 (2002) 339-347.

[38] Wilson T., Wu Xi-Yang, Juengel J.L., Ross I.K., Lumsden J.M., Lord E.A., Dodds K.G., Walling G.A., McEwan J.C., O'Connell A.R., McNatty K.P., Montgomery G.W., Highly prolific Booroola sheep have a mutation in the intracellular kinase domain of bone morphogenetic protein IB receptor (ALK6) that is expressed in both oocytes and granulosa cells, Biol. Reprod. 64 (2001) 1225-1235.

To access this journal online: www.edpsciences.org 
